\title{
RENCANA PENATAAN KAWASAN TRANSIT WATERWAY (TRANSPORTASI AIR) SUNGAI CISADANE KOTA TANGERANG
}

\author{
Muhamad Ichsan Zafiri ${ }^{1)}$, Suryono Herlambang ${ }^{2)}$, Parino Rahardjo ${ }^{3)}$ \\ 1)Program Studi S1 PWK, Fakultas Teknik, Universitas Tarumanagara, muhamad.3451600@stu.untar.ac.id \\ 2) Program Studi S1 PWK, Fakultas Teknik, Universitas Tarumanagara, s.herlambang@gmail.com \\ 3) Program Studi S1 PWK, Fakultas Teknik, Universitas Tarumanagara, parinor19@gmail.com
}

Masuk: 11-08-2020, revisi: 08-09-2020, diterima untuk diterbitkan: 25-09-2020

\begin{abstract}
Abstrak
Kota Tangerang berencana melakukan pengembangan transportasi air dalam rangka menyediakan pilihan moda transportasi selain transportasi darat, rencana pengembangan transportasi tersebut adalah pengembangan transportasi air dengan memanfaatkan sungai cisadane sebagai jalurnya, salah satu rencana titik dermaga yakni dermaga masjid agung alijtihad berada di pusat Kota Tangerang dan berada dekat dengan Stasiun KRL Tangerang, sehingga adanya potensi dari dekatnya letak kedua moda transportasi tersebut. Tujuan dari penelitian ini adalah untuk mengetahui kelayakan dan daya dukung sungai cisadane untuk dimanfaatkan dalam pengembangan transportasi air dan mengetahui kebutuhan sarana, prasarana dan fasilitas yang dibutuhkan untuk mengintegrasikan rencana dermaga transportasi air masjid agung al-ijtihad sungai cisadane dengan stasiun KRL Tangerang. Jenis penelitian ini merupakan penelitian kualitatif dan kuantitatif dengan menggunakan metode analisis deskriptif dalam pembahasan keseluruhan analisisnya. Kemudian dari seluruh analisis yang telah dilakukan, didapatkanlah arahan rencana penataan yang secara garis besar meliputi penyediaan ruang terbuka, pelebaran pedestrian, rekomendasi pemindahan akses keluar/masuk stasiun KRL Tangerang yang kemudian hasilnya berupa usulan rencana siteplan kawasan yang didalam rencananya terdapat unsur penyediaan kebutuhan sarana, prasarana dan fasilitas pada sekitar kawasan transit transportasi air dan penataan yang sesuai dengan arahan integrasi kawasan antarmoda.
\end{abstract}

Kata kunci: integrasi antarmoda; perencanaan area transit; stasiun kereta api; transportasi air

\begin{abstract}
Tangerang City plans to develop water transportation in the context of providing transportation modes other than land transportation, the transportation development plan is the development of water transportation by utilizing the cisadane river as its route, one of the docks planned namely the dock of the great al-ijtihad mosque located in the center of Tangerang City and close to the Tangerang KRL Station, so there is potential for the proximity of the two modes of transportation. The purpose of this research is to determine the feasibility and carrying capacity of the cisadane river to be utilized in the development of water transportation and to determine the need for infrastructure and facilities needed to integrate the water transportation wharf plan of the grand mosque of Al-ijtihad cisadane river with Tangerang KRL station.. This type of research is qualitative and quantitative research using descriptive analysis methods in the overall analysis of the analysis. Then from all the analyzes that have been carried out, it is obtained the direction of the structuring plan which broadly includes the provision of open space, widening pedestrian, recommendations for moving out / entering the Tangerang KRL station and the results are in the form of a regional site plan which is planned to contain elements of the provision of facilities, infrastructure and facilities in the vicinity of the water transportation transit area and arrangement in accordance with the direction of intermodal area integration.
\end{abstract}

Keywords: intermoda integration; railway station; transit area planning; water transportation 


\section{PENDAHULUAN}

\section{Latar Belakang}

Salah satu kota yang berencana untuk mengembangkan transportasi air yakni Kota Tangerang, dengan memanfaatkan Sungai Cisadane pembangunan transportasi air ini sebagai bagian dalam program penataan revitalisasi sungai yang mengaliri 48 Kecamatan di Kota Tangsel, Kota Tangerang, dan Kabupaten Tangerang tersebut. Pemerintah Kota Tangerang memasukan program pengembangan waterway di Sungai Cisadane sebagai alternatif transportasi yang tertuang dalam Rencana Pembangunan Jangka Menengah Daerah (RPJMD) 2018-2023. Hal ini disampaikan juga oleh Wali Kota Tangerang yakni Arief R Wismansyah, beliau menegaskan "Rencana pembangunan waterway di Kota Tangerang sudah masuk dalam RPJMD 2018-2023, Jadi, nantinya waterway Cisadane bisa menjadi moda transportasi air. Selain itu, bisa menjadi daya tarik wisatawan yang datang ke Kota Tangerang untuk bisa merasakan waterway Cisadane." Diharapkan pembangunan waterway bisa mengurangi kemacetan yang ada di Kota Tangerang. Nantinya, perahu yang disediakan untuk transportasi akan melayani dari perbatasan kota sampai ke pusat Kota Tangerang. Wali Kota Tangerang Arief $\mathrm{R}$ Wismansyah menjelaskan "Kami akan siapkan beberapa dermaga pemberhentian, di antaranya Dermaga Serpong yang berlokasi dibelakang Lippo ke Panungangan Barat yang kemudian berhentinya di Masjid Agung Cikokol." Pengembangan transortasi air di Kota Tangerang ini juga masuk ke dalam Rencana Induk Transportasi Daerah Kota Tangerang 2018-2038 dan draft revisi Perda Rencana Tata Ruang Wilayah Kota Tangerang 2012-2032 pasal 13 ayat 1 huruf c yakni sistem jaringan sungai danau dan penyebrangan.

Titik transit waterway yang berada di Kecamatan Tangerang Kelurahan Sukarasa Masjid Agung lokasinya berdekatan dengan Stasiun KRL Tangerang yang berada di depan masjid agung dengan jarak yang \pm 300 meter yang berarti adanya suatu potensi dari dekatnya jarak antara stasiun KRL Tangerang dengan titik transit waterway tersebut, jadi nantinya masyarakat yang bertujuan pergi ke DKI Jakarta atau sekitarnya dapat melanjutkan perjalanannya dengan menggunakan KRL di Stasiun Tangerang begitu pun sebaliknya masyarakat yang sehabis menggunakan KRL dapat memilih opsi untuk melanjutkan perjalanannya dengan waterway.

\section{Rumusan Permasalahan}

Rencana pengembangan transportasi air yang masuk kedalam RPJMD Kota Tangerang 20182023, draft revisi RTRW Kota Tangerang 2012-2032, RITD Kota Tangerang 2018-2038 dapat dipastikan akan dilaksanakan pembangunannya tetapi belum diketahui daya dukung dari sungai cisadane terhadap rencana pengembangan transportasi air, pada objek lokasi saat ini belum terdapat sarana, prasarana dan fasilitas penunjang disekitar kawasan dan juga belum diketahuinya minat masyarakat dalam menggunakan transportasi air di sungai cisadane Kota Tangerang.

\section{Tujuan}

Membuat konsep penataan kawasan transit transportasi air dermaga masjid agung yang terintegrasi dengan Stasiun KRL Tangerang dengan cara:

a. Mengidentifikasi kawasan sekitar rencana dermaga pengembangan transportasi air sungai cisadane.

b. Mengetahui kelayakan dan daya dukung sungai cisadane untuk dimanfaatkan dalam pengembangan transportasi air.

c. Mengetahui kebutuhan sarana, prasarana dan fasilitas yang dibutuhkan untuk mengintegrasikan rencana dermaga transportasi air masjid agung al-ijtihad sungai cisadane dengan stasiun KRL Tangerang. 


\section{KAJIAN LITERATUR}

\section{Penataan Kawasan}

Penataan kawasan merupakan sebuah usaha yang dilakukan dalam rangka rekayasa sosial suatu wilayah/area bersamaan dengan upaya menciptakan suatu sistem yang komperehensif terkait aktivitas yang berlangsung serta memperhatikan kualitas lingkungan hidup di wilayah/area.

\section{Transportasi}

Transportasi dapat diartikan usaha memindahkan, mengerakkan, mengangkut, atau mengalihkan suatu objek dari suatu tempat ke tempat lain, di mana di tempat lain ini objek tersebut lebih bermanfaat atau dapat berguna untuk tujuan-tujuan tertentu (Miro, 2005). Angkutan sungai dan danau adalah kegiatan angkutan dengan menggunakan kapal yang dilakukan di sungai, danau, waduk, rawa, anjir, kanal dan terusan untuk mengangkut penumpang, barang dan/atau hewan, yang diselenggarakan oleh perusahaan angkutan sungai dan danau (PP 82, 1999 pasal 1)

\section{Pedoman Integrasi Antarmoda}

Desain integrasi antarmoda yang berfokus kepada: 1) Kecepatan akses penumpang; 2) Kemudahan penumpang; 3) Keterjangkauan tarif; 4) Lokasi kebutuhan integrasi.

\section{TUJUAN INTEGRASI}

\section{Lebih Cepat}

Memangkas waktu tunggu dan waktu transfer

\section{Lebih Mudah}

Memperpendek Jarak kakı, memperjelas Informası, dan rasa nyaman dalam satu sistem

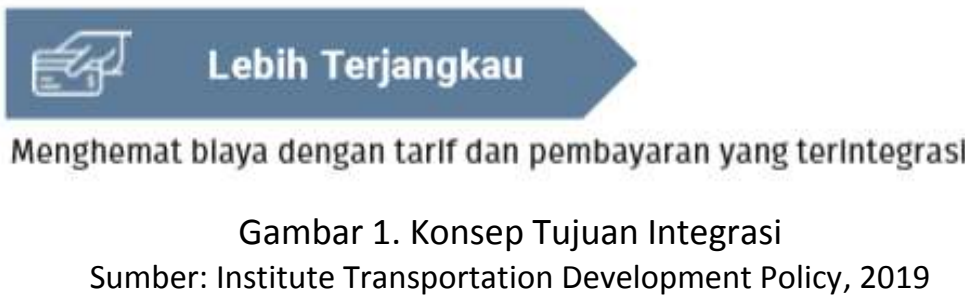

\section{Integrasi Kawasan}

Integrasi kawasan difokuskan kepada aksesibilitas dan konektivitas dalam radius 500 meter dari setiap stasiun atau halte angkutan umum massal yang ada. Pergerakan pejalan kaki difasilitasi agar nyaman, aman, dan menarik di kawasan antarmoda dengan elemen sebagai berikut:

a. Trotoar yang lebar

b. Peneduhan \& pencahayaan yang baik

c. Aktivasi ruang publik untuk berinteraksi

\section{Jalur Pejalan Kaki}

Menurut Departemen Pekerjaan Umum (1999), jalur pejalan kaki merupakan lintasan yang diperuntukan untuk berjalan kaki yang bertujuan untuk memberikan pelayanan kepada pejalan kaki. Jaluran pejalan kaki dapat berupa trotoar, penyeberangan sebidang (penyebrangan zebra dan penyeberangan pelican), dan penyeberangan tidak sebidang. 


\section{METODE}

\section{Lokasi Penelitian}

Lokasi objek penelitian penulis yang diteliti adalah titik dermaga Masjid Agung Sungai Cisadane, Kota Tangerang, tepatnya berlokasi di Jalan Kalipasir Indah, Kelurahan Sukarasa, Kecamatan Tangerang Kota Tangerang Provinsi Banten.

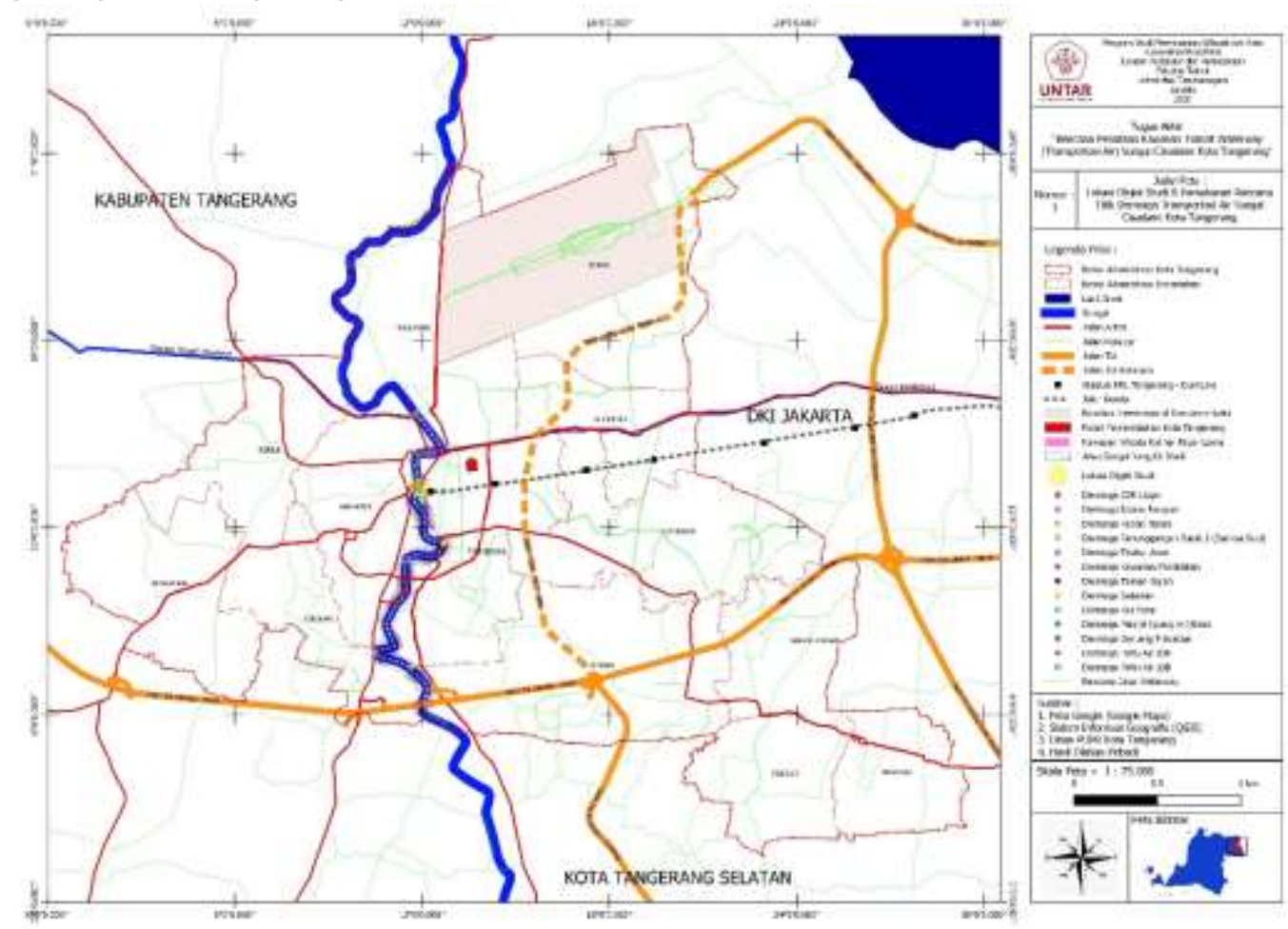

Gambar 2. Lokasi Penelitian

Sumber: Hasil Olahan Pribadi, 2020

\section{Metode Pengumpulan Data}

Dalam penelitian ini terdapat dua metode pengumpulan data, antara lain sebagai berikut.

a. Data Primer

Data primer merupakan data yang didapat langsung dari objek penelitian, bukan dari sumber lain. Pengumpulan data primer yaitu sebagai berikut.

1. Survei lapangan meliputi profil objek studi, kondisi fisik eksisting di kawasan titik transit waterway Sungai Cisadane Masjid Agung Dan Stasiun KRL Tangerang.

2. Melakukan wawancara kepada pihak instansi terkait (Dinas PUPR, Bappeda dan Dinas Perhubungan)

3. Melakukan penyebaran kuisioner kepada pengguna KRL di Stasiun Tangerang dan penduduk dari daerah asal sekitar titik transit waterway lainnya sepanajang Sungai Cisadane.

4. Dokumentasi foto yang didapatkan langsung saat survei lokasi

b. Data Sekunder

Data sekunder didapatkan dari berbagai sumber lain seperti dokumen pemerintah, jurnal, artikel, buku, serta sumber dari internet yang dapat dipertanggungjawabkan.

\section{Metode Analisis}

Analisis deskriptif merupakan suatu analisis yang dilakukan untuk memperoleh suatu gambaran tentang suatu hal dengan penyajian hasil peringkasan atau penelitian tersebut. Tujuannya adalah agar data yang akan disajikan dalam bentuk yang lebih mudah dan lebih cepat dimengerti serta dipahami oleh pembaca. 


\section{DISKUSI DAN HASIL}

Pada bagian diskusi dan hasil ini membahas dua bagian garis besar penelitian yang dilakukan, yang pertama yakni membahas mengenai rencana pengembangan transportasi air sungai cisadane dan selanjutnya membahas mengenai rencana penataan yang dilakukan pada salah satu rencana dermaga transportasi air sungai cisadane yakni dermaga masjid agung al-ijtihad dengan tujuan mengintegrasikan kawasan antarmoda dari rencana dermaga masjid agung alijtihad dengan stasiun KRL Tangerang.

\section{Identifikasi Area Sekitar Rencana Dermaga Transportasi Air Sungai Cisadane}

Pada Gambar 3 dan 4 peta identifikasi perumahan dan kawasan eksisting sekitar rencana titik dermaga, menunjukan kawasan eksisting sekitar rencana titik dermaga sepanjang sungai sebagai daerah asal calon potensi pengguna transportasi air untuk menuju titik dermaga yang ada di masjid agung (objek lokasi). Dapat dilihat bahwa kawasan sekitar rencana titik dermaga terdapat beberapa kawasan seperti perumahan lippo karawaci utara, Hotel dan Restaurant Istana Nelayan dan Apartemen Great Western Residence Serpong, Perumahan Kavling Pemda Tangerang, Perumahan Swadaya, Kawasan Pendidikan Cikokol, Ruang Terbuka Publik CSR Taman Gajah, Kampung Warna-Warni Kota Tangerang dan Kawasan Wisata Kuliner Pasar Lama.

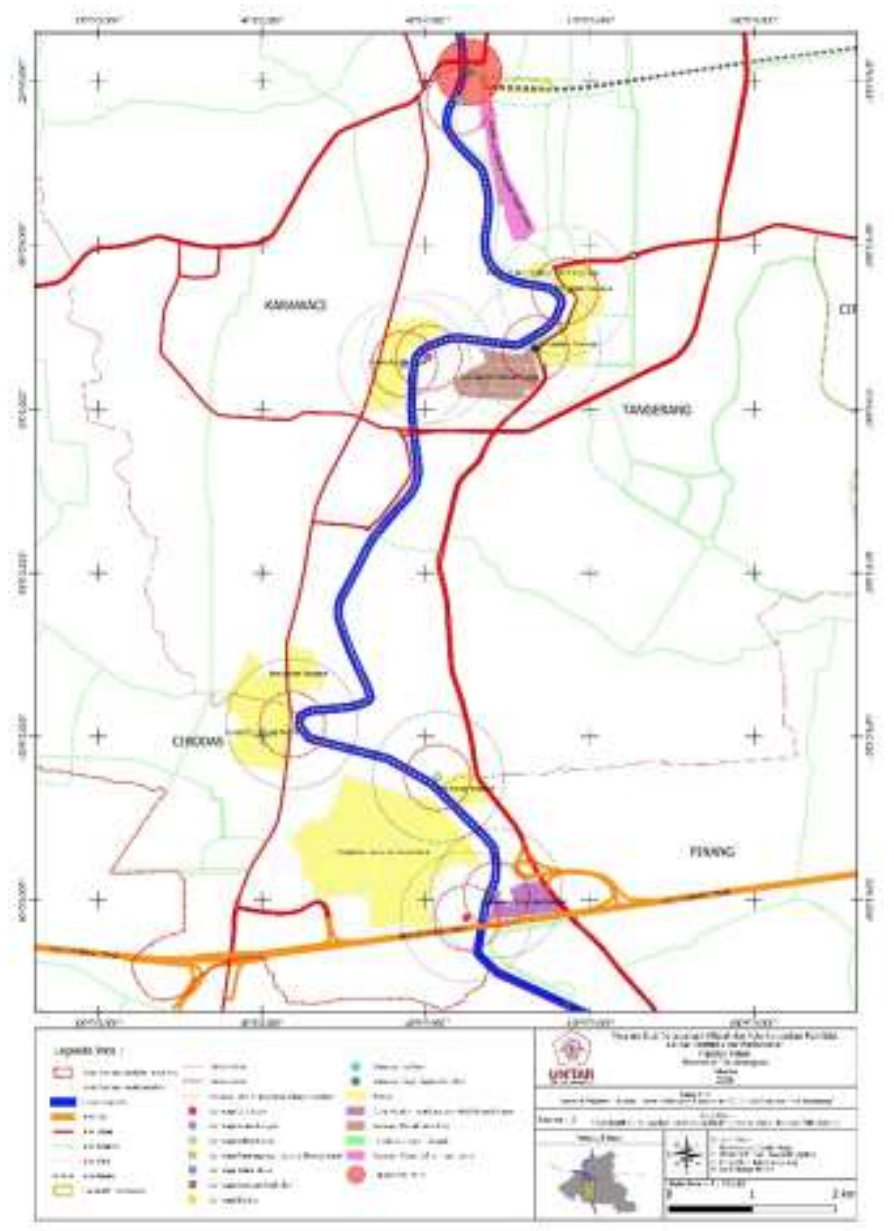

Gambar 3. Peta Identifikasi Perumahan dan Kawasan Eksisting Sekitar Radius Rencana Titik Dermaga Sumber: Google Maps/QGIS/Hasil Olahan Penulis, 2020 

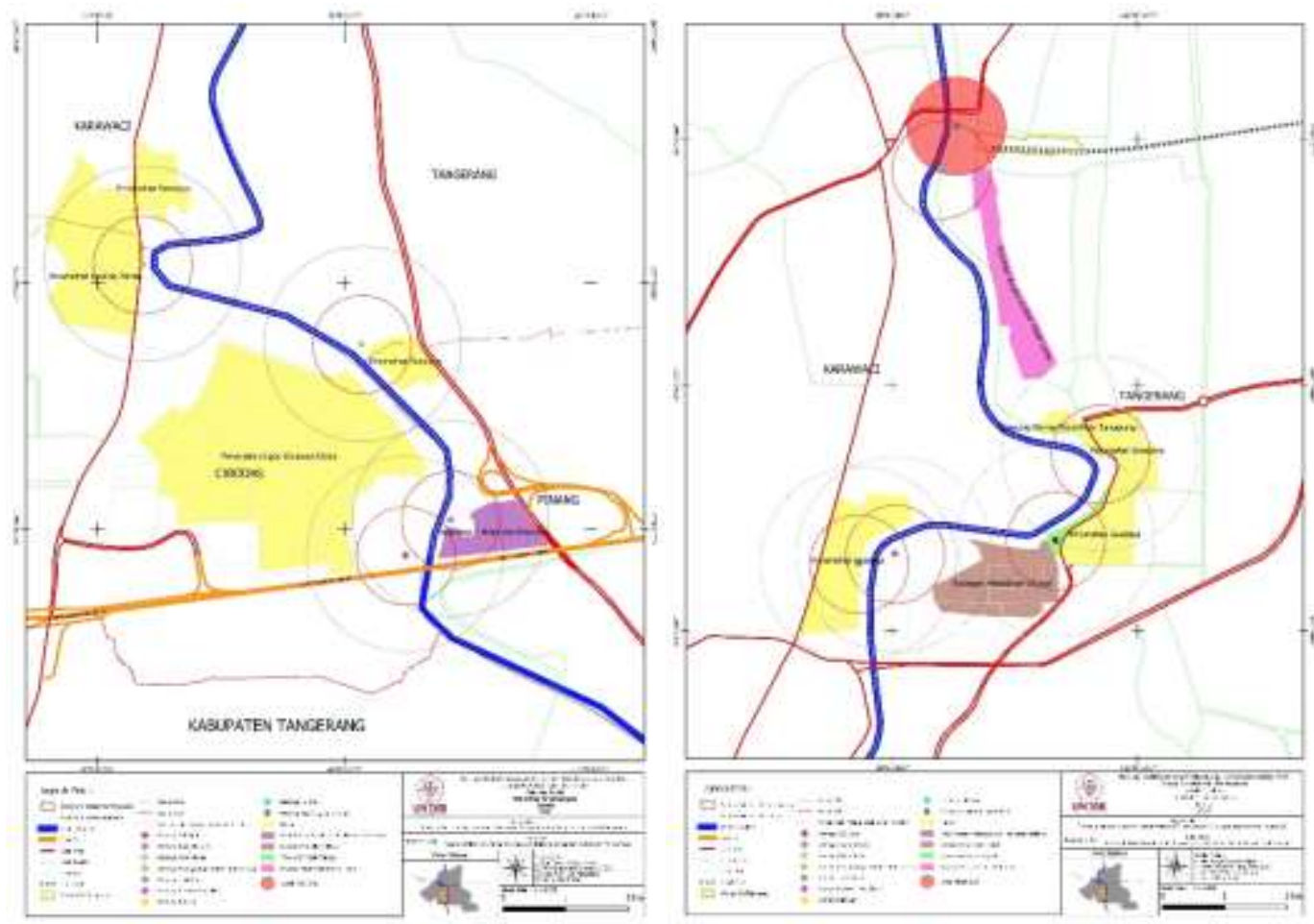

Gambar 4. Identifikasi Perumahan dan Kawasan Eksisting Sekitar Radius Rencana Titik Dermaga (Peta Penggal A dan Peta Penggal B)

Sumber: Google Maps/QGIS/Hasil Olahan Penulis, 2020

\section{Daya Dukung Sungai Cisadane Untuk Pengembangan Transportasi Air}

Dari data Tabel 1 dapat dilihat bahwa tinggi permukaan air sungai rata-rata setiap tahun berada pada tinggi 12 meter, tinggi permukaan air tertinggi terjadi pada tahun 2020 dengan tinggi 12,54 meter sedangkan tinggi permukaan air terendah terjadi di tahun 2019 dengan tinggi 10,95 meter. Dari data di atas terlihat bahwa ketinggian permukaan air sungai cisadane tinggi dan stabil setiap tahunnya, sangat memungkinkan dan mendukung untuk dimanfaatkan untuk pengembangan transportasi air.

Tabel 1. Data Tinggi Perumukaan Air Sungai Cisadane Rata-rata/Tahun

\begin{tabular}{cccc}
\hline Tahun & $\begin{array}{c}\text { Tinggi Permukaan Air } \\
\text { Rata-rata/Tahun (Meter) }\end{array}$ & $\begin{array}{c}\text { Tinggi Permukaan Air } \\
\text { Terendah (Meter) }\end{array}$ & $\begin{array}{c}\text { Tinggi Permukaan Air } \\
\text { Tertinggi (Meter) }\end{array}$ \\
\hline 2016 & 12.28 & 11.50 & 12.50 \\
\hline 2017 & 12.22 & 11.50 & 12.50 \\
\hline 2018 & 12.19 & 11.00 & 12.50 \\
\hline 2019 & 12.14 & 10.95 & 12.50 \\
\hline 2020 (Sampai & 12.16 & 11.00 & 12.54
\end{tabular}

Sumber: Balai Pengelolaan Sumber Daya Air Cisadane-Cidurian, 2020

Tabel 2. Spesifikasi Rencana Kapal Transportasi Air

\begin{tabular}{cc}
\hline Spesifikasi Kapal & Ukuran \\
\hline Panjang & $12 \mathrm{M}$ \\
\hline Tinggi & $1,45 \mathrm{M}$ \\
\hline Lebar & $2,8 \mathrm{M}$
\end{tabular}

Sumber: Balai Pengelolaan Sumber Daya Air Cisadane-Cidurian, 2020 
Jika kita bandingkan dengan spesifikasi kapal pada Tabell 2 yaitu dengan tinggi kapal 1,45 meter ketinggian permukaan air sungai cisadane sudah lebih dari mencukupi untuk dimanfaatkan sebagai jalur transportasi air. Ditambah menurut pihak Balai Pengelolaan Sumber Daya Air Cisadane-Cidurian sungai cisadane hampir tidak mungkin akan mengalami kekeringan atau penurunan ketinggian permukaan air yang signifikan, menurut mereka jika memang nantinya transportasi air sudah mulai beroperasi, pihak dari penyelenggara transportasi air bisa berkoordinasi dengan pihak Balai Pengelolaan SDA CisadaneCidurian terkait pemanfaatan transportasi air. Seperti contoh sebagaimana yang mereka paparkan, mereka dapat mengatur kecepatan aliran sungai cisadane dengan menutup sebagian pintu air yang ada bendungan pasar baru jika dalam pemanfaatan sungai untuk transportasi air membutuhkan aliran sungai yang tenang atau juga jika terjadi hujan besar yang menyebabkan volume debit air naik dan tinggi permukaan sungai menjadi tinggi juga bisa disesuaikan dengan kebutuhan untuk pemanfaatan transportasi air tersebut.

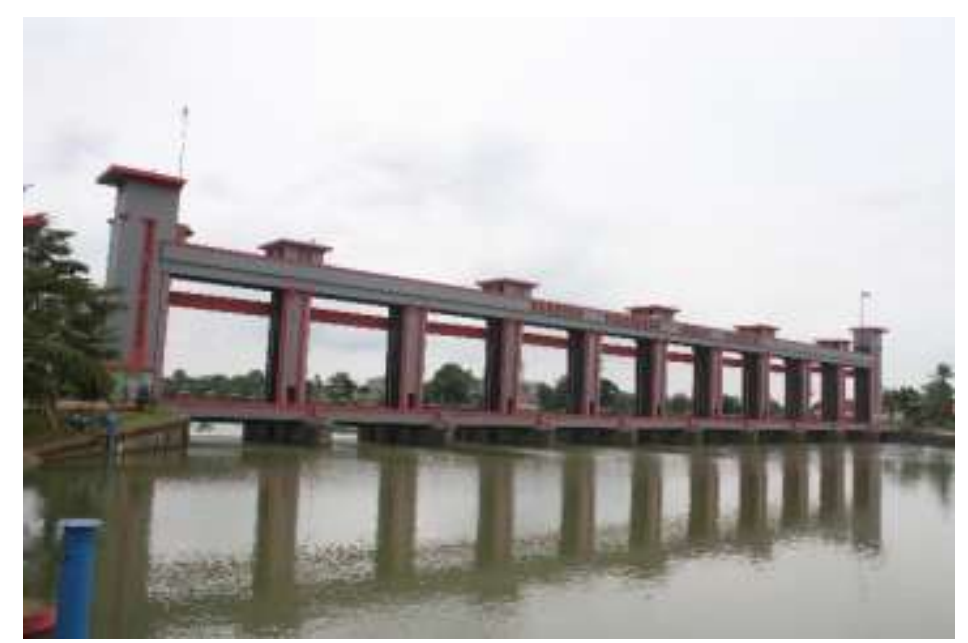

Gambar 5. Bendungan Pasar Baru/Pintu Air 10 Cisadane Sumber: Survei Lapangan, 2020

\section{Rencana Penataan Pada Kawasan}

Pada bagian ini berisi mengenai rincian penataan yang didapatkan setelah melakukan seluruh analisis, terbagi menjadi rincian rencana penataan lahan dan rincian rencana penataan jalan pada kawasan.

Tabel 3. Rencana Penataan Jalan Yang Ada di Kawasan

\begin{tabular}{|c|c|c|}
\hline Jalan & Rencana & Dasaran \\
\hline \multirow[t]{5}{*}{ Jalan Merdeka } & $\begin{array}{l}\text { Penataan jaringan pejalan } \\
\text { kaki dan ramah difabel }\end{array}$ & $\begin{array}{l}\text { Peraturan Menteri Pekerjaan } \\
\text { Umum Nomor 03/PRT/M/2014 }\end{array}$ \\
\hline & Lampu penerangan & \\
\hline & Penyediaan signage & ITDP \\
\hline & Pelican cross & \\
\hline & Jalur sepeda & RTRW Kota Tangerang 2012-2032 \\
\hline \multirow[t]{6}{*}{ Jalan Kisamaun } & $\begin{array}{l}\text { Penataan jaringan pejalan } \\
\text { kaki dan ramah difabel }\end{array}$ & $\begin{array}{l}\text { Peraturan Menteri Pekerjaan } \\
\text { Umum Nomor 03/PRT/M/2014 }\end{array}$ \\
\hline & Lampu penerangan & \\
\hline & Penyediaan signage & ITDP \\
\hline & Pelican cross & \\
\hline & Rute BRT Kota Tangerang & RTRW Kota Tangerang 2012-2032 \\
\hline & Halte & Analisis Lokasi \\
\hline
\end{tabular}




\begin{tabular}{|c|c|c|}
\hline Jalan & Rencana & Dasaran \\
\hline \multirow[t]{4}{*}{ Jalan Kiasnawi } & $\begin{array}{l}\text { Penataan jaringan pejalan } \\
\text { kaki dan ramah difabel }\end{array}$ & $\begin{array}{l}\text { Peraturan Menteri Pekerjaan } \\
\text { Umum Nomor 03/PRT/M/2014 }\end{array}$ \\
\hline & Lampu penerangan & \\
\hline & Pelican cross & ITDP \\
\hline & Penyediaan signage & \\
\hline \multirow[t]{6}{*}{$\begin{array}{l}\text { Jalan Kalipasir } \\
\text { Indah }\end{array}$} & $\begin{array}{l}\text { Penataan jaringan pejalan } \\
\text { kaki dan ramah difabel }\end{array}$ & $\begin{array}{l}\text { Peraturan Menteri Pekerjaan } \\
\text { Umum Nomor 03/PRT/M/2014 }\end{array}$ \\
\hline & Pelican cross & ITDP \\
\hline & Penyediaan signage & \\
\hline & Lampu penerangan & \\
\hline & Jalur sepeda & RTRW Kota Tangerang 2012-2032 \\
\hline & Riverwalk & Benchmark Sungai Melaka \\
\hline
\end{tabular}

Sumber: Hasil Olahan Pribadi, 2020

Tabel 4. Rencana Penataan pada Lahan di Kawasan

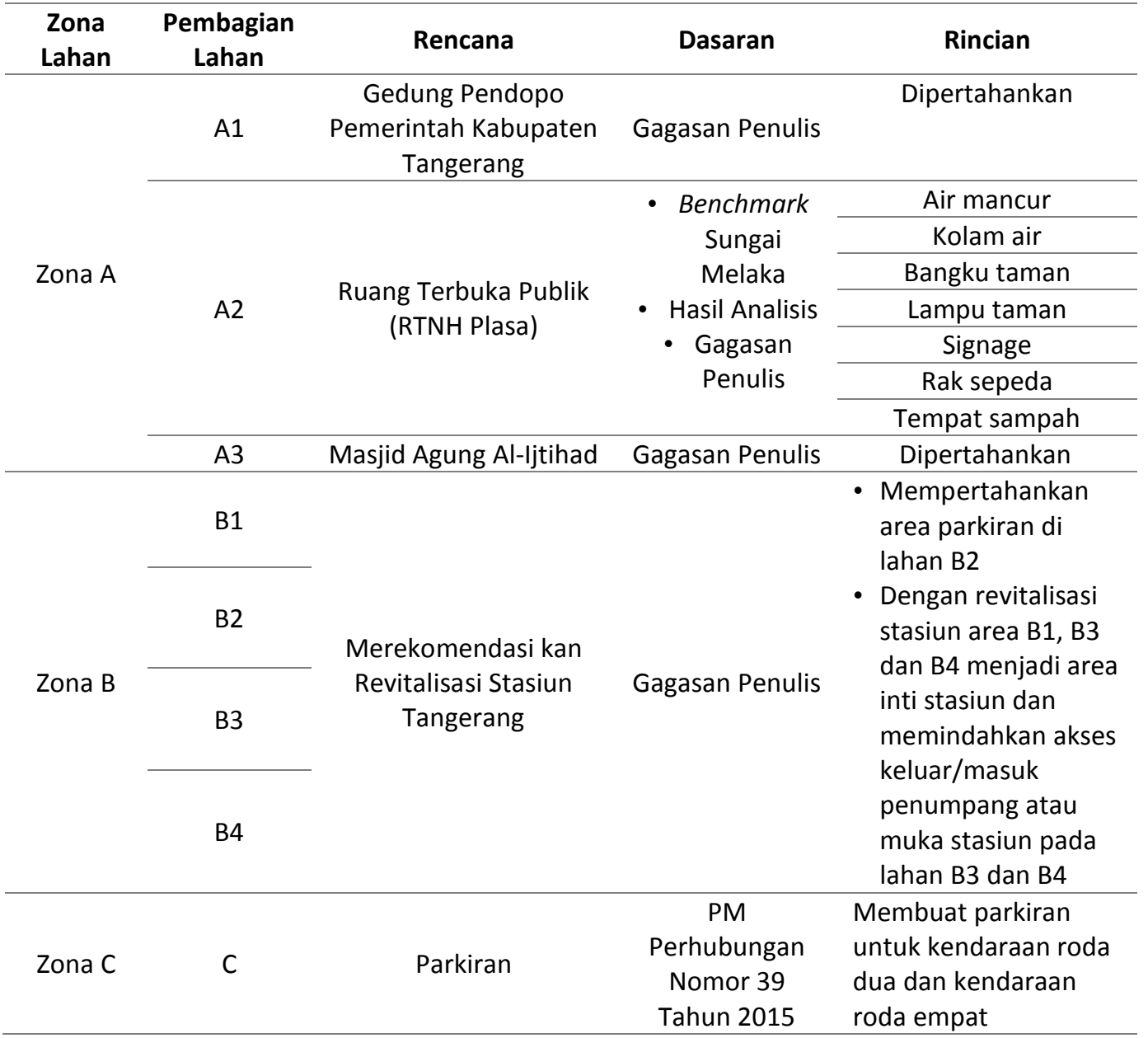

Sumber: Hasil Olahan Pribadi, 2020

\section{Rencana Jaringan Jalan}

Pada rencana jaringan jalan berdasarkan dari analisis yang dilakukan, arahan penataannya berupa pelebaran pedestrian sesuai standar minimal dan ramah difabel sesuai peraturan SE Menteri PUPR Nomor 02/SE/M/2018. Berikut gambar rencana potongan jalan pada kawasan objek studi. 

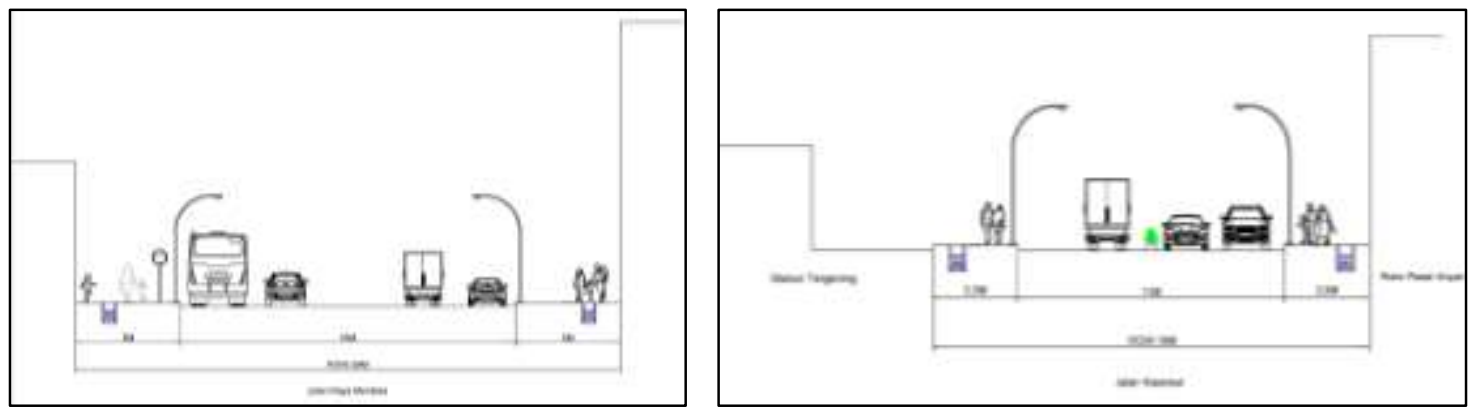

Gambar 6. Rencana Jalan pada Kawasan Objek Studi

(kiri: Jalan Merdeka Raya, kanan: Jalan Kiasnawi) Sumber: Hasil olahan penulis, 2020

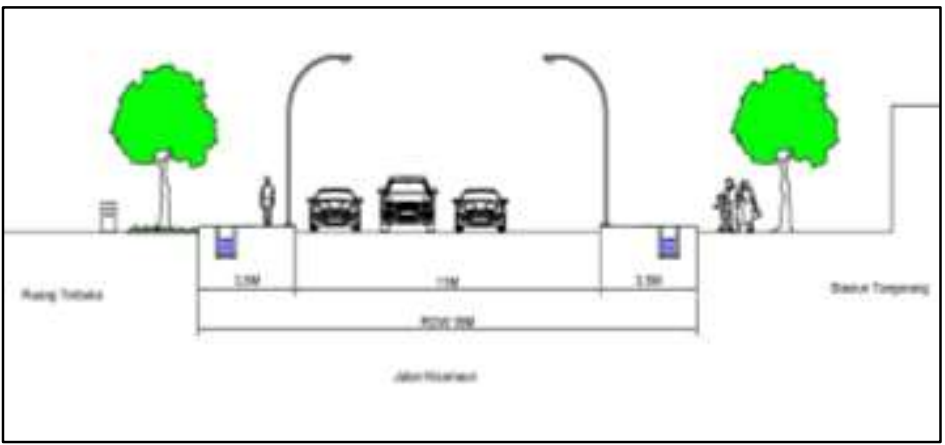

Gambar 7. Rencana Jalan pada Kawasan Objek Studi (Jalan Kisamaun) Sumber: Hasil olahan penulis, 2020

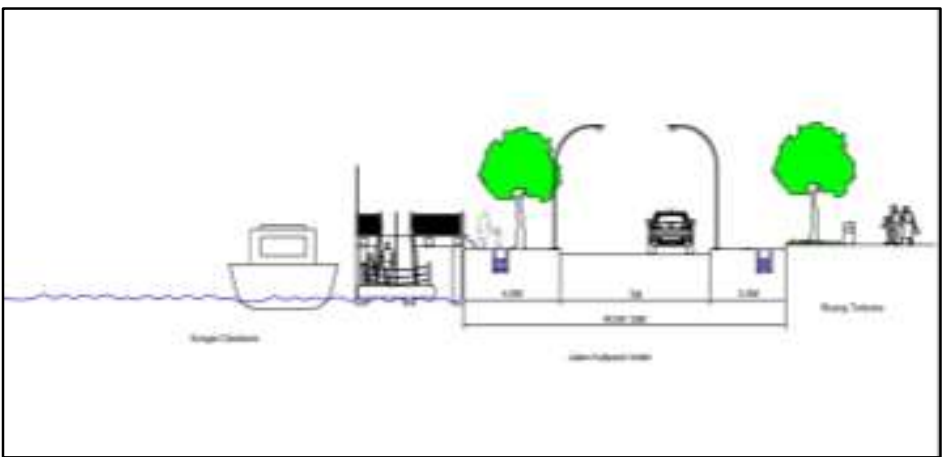

Gambar 8. Rencana Jalan pada Kawasan Objek Studi (Jalan Kalipasir Indah) Sumber: Hasil olahan penulis, 2020

\section{Rencana Siteplan Pada Kawasan}

Pada Gambar 9 merupakan peta usulan rencana siteplan pada kawasan, terdapat beberapa rencana mulai dari rencana jalur dan halte BRT Trans Kota Tangerang, rencana jalur dan shelter sepeda, rencana potongan jalan, rencana ruang terbuka dengan konsep RTNH plasa dan rencana detail siteplan kawasan dan integrasi dermaga transportasi air dengan stasiun KRL Tangerang. Gambar 10, 11, 12 dan 13 merupakan beberapa gambar ilustrasi kawasan dari rencana diatas. 


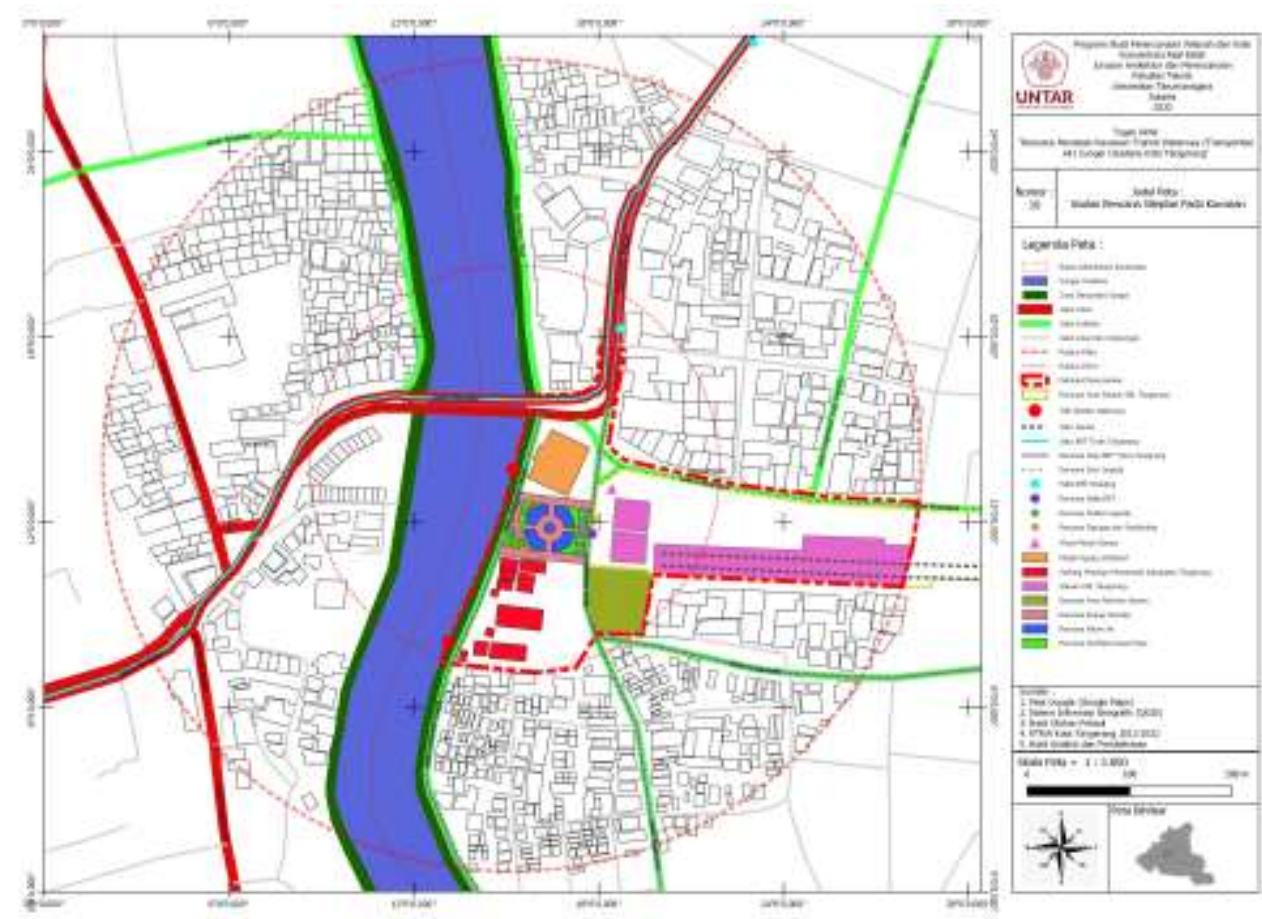

Gambar 9. Peta Usulan Rencana Siteplan pada Kawasan Sumber: Hasil olahan pribadi, 2020
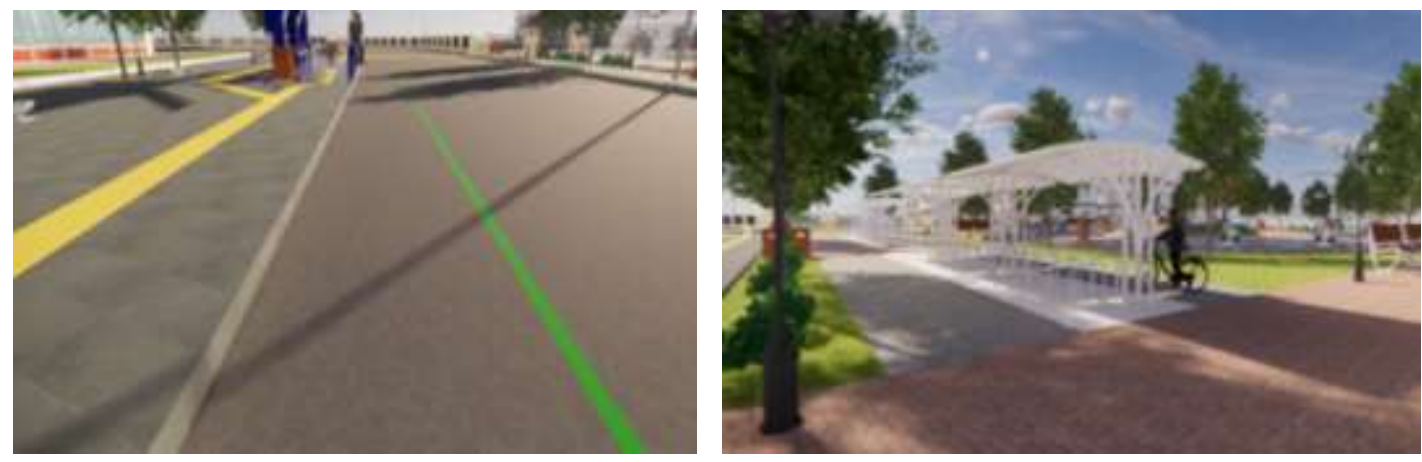

Gambar 10. Ilustrasi Rencana Jalur dan Shelter Sepeda Sumber: Hasil olahan pribadi, 2020

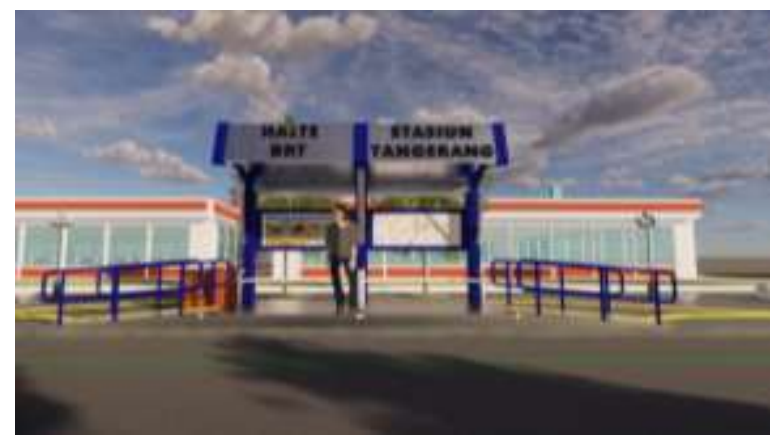

Gambar 11. Ilustrasi Rencana Halte BRT Trans Kota Tangerang Sumber: Hasil olahan pribadi, 2020 

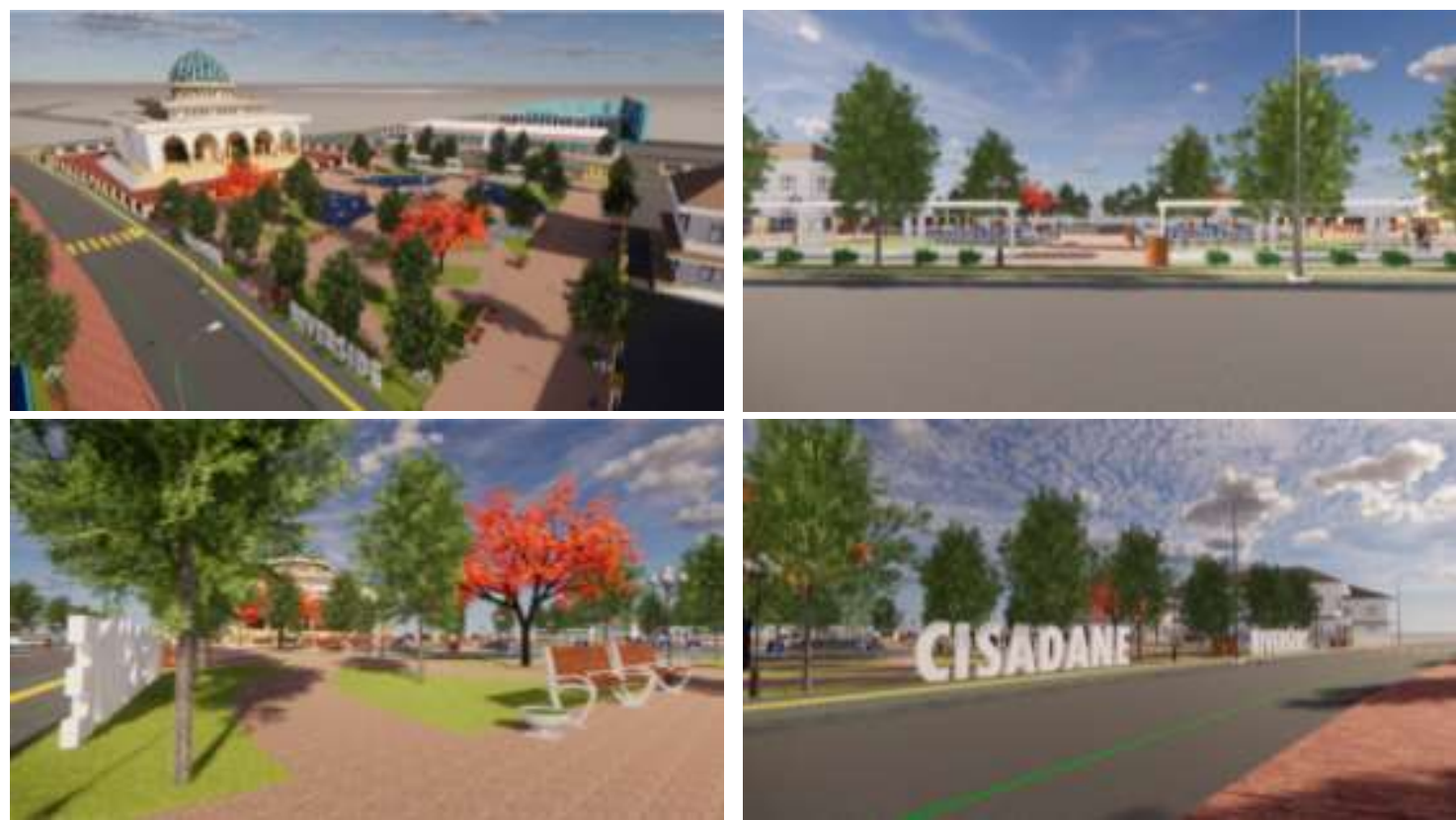

Gambar 12. Ilustrasi Rencana Ruang Terbuka Pada Kawasan Objek Studi Sumber: Hasil olahan pribadi, 2020

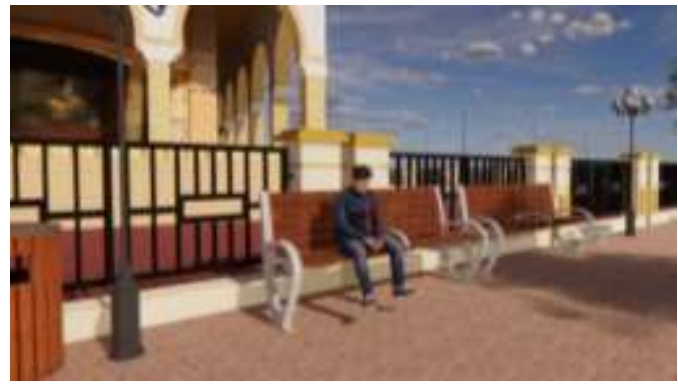

Bangku Taman

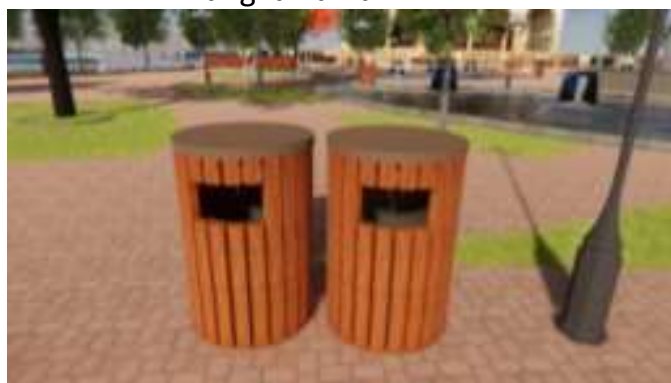

Tempat Sampah

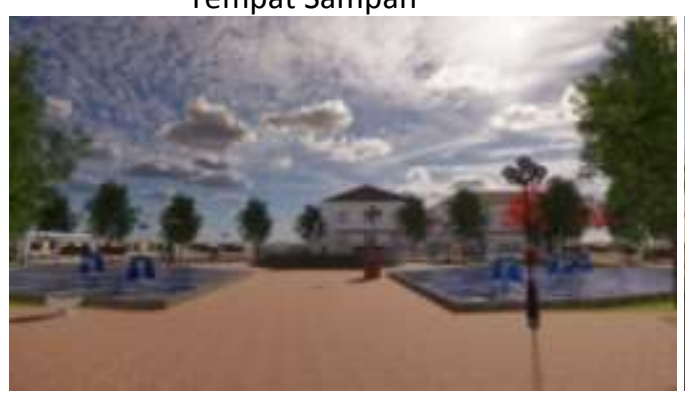

Kolam Air

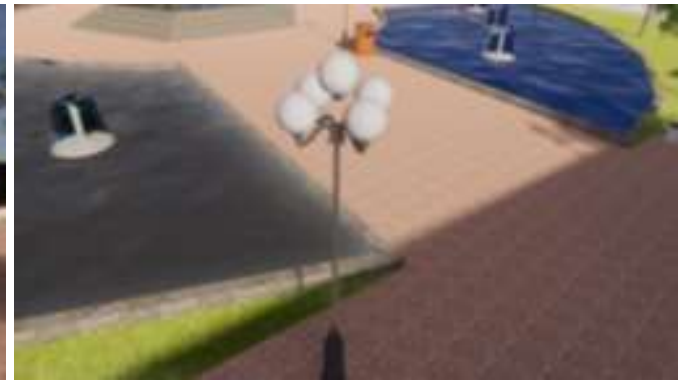

Lampu Taman

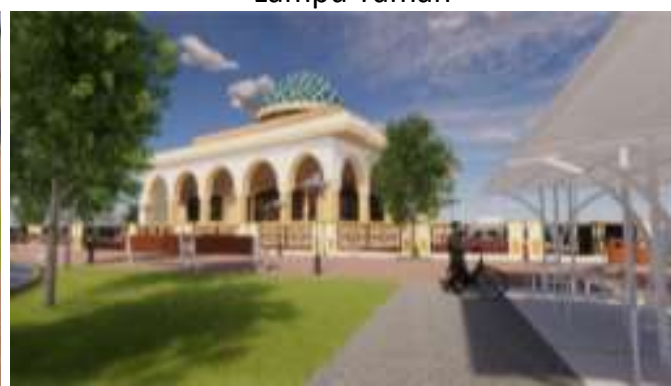

Shelter Sepeda

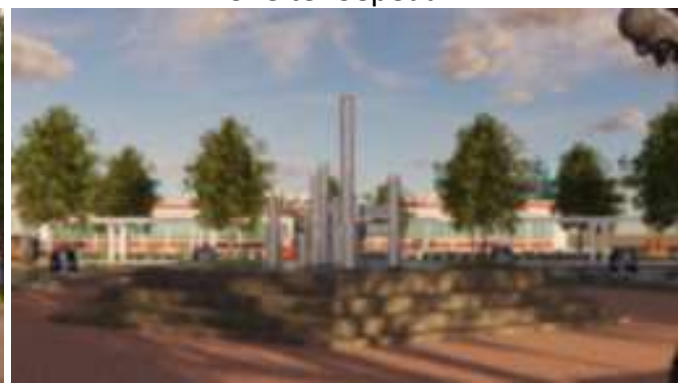

Gambar 13. Ilustrasi Prasarana Penunjang Yang Terdapat Pada Rencana Ruang Terbuka Sumber: Hasil Olahan Pribadi, 2020 


\section{Detail Usulan Rencana Siteplan Pada Kawasan}

Pada gambar diatas merupakan gambar detail usulan rencana siteplan pada kawasan objek studi, pada gambar diatas telah terlihat beberapa detail rencana penataan mulai dari penataan pedestrian yang sesuai dengan standar minimal dan ramah difabel, lokasi dan ukuran rencana halte BRT, jalur sepeda, lokasi dan ukuran rencana shelter sepeda, rencana area parkiran stasiun, rencana akses masuk/keluar stasiun, lokasi dan ukuran dermaga transportasi air dan rencana ruang terbuka yang bisa digunakan sebagai fasilitas publik dan area pendukung dari kawasan transit transportasi air di masjid agung al-ijtihad yang nantinya akan menjadi akses untuk sirkulasi pejalan kaki dalam melakukan perpindahan moda transportasi dari dermaga transportasi air menuju stasiun KRL Tangerang ataupun sebaliknya. Berikut penjelasan lebih rincinya mengenai rencana integrasinya.

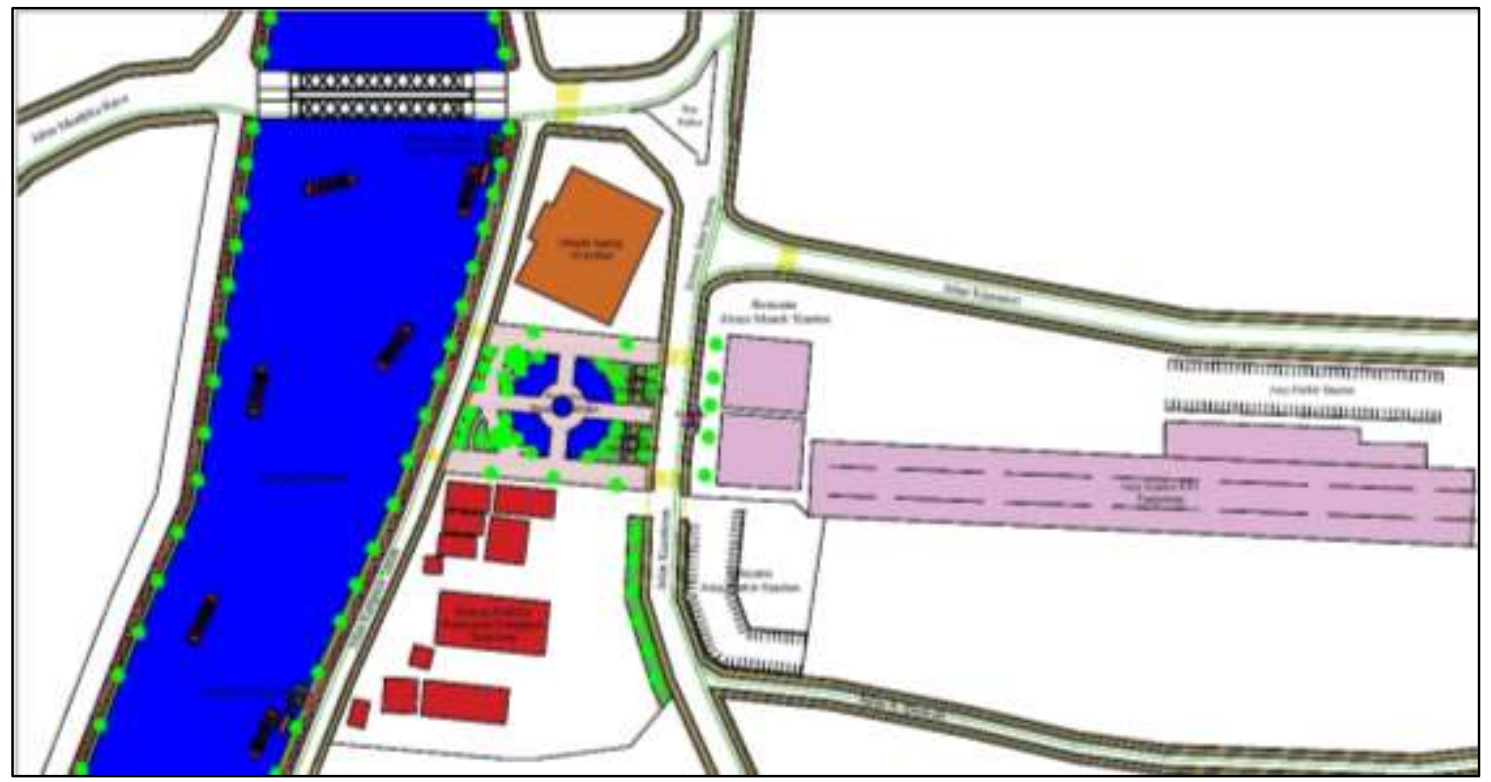

Gambar 14. Detail Usulan Rencana Siteplan Kawasan Objek Studi

Sumber: Hasil Olahan Pribadi, 2020

Pada Gambar 15 merupakan penjelasan mengenai sirkulasi pejalan kaki dari dermaga transportasi air menuju stasiun KRL Tangerang ataupun sebaliknya, sirkulasi pejalan kaki dilakukan dengan berjalan melewati pedestrian disisi sungai cisadane kemudian menyebrangi jalan kalipasir indah dengan melewati pelican cross kemudian berjalan masuk melewati rencana ruang terbuka dan berjalan kearah jalan kisamaun menyebrangi lagi dengan melewati pelican cross dan masuk ke arah rencana akses masuk/keluar stasiun yang letak dan posisinya dekat berada didepan rencana ruang terbuka. Jarak tempuh pejalan kaki dengan sirkulasi pejalan kaki rencana ini memiliki jarak \pm 150 meter, yang artinya lebih dekat dan lebih nyaman bagi pejalan kaki untuk melakukan perpindahan moda transportasi. Selain sirkulasi pejalan kaki yang menjadi lebih dekat, adapun bagian dari komponen integrasi antarmoda yakni dengan dilakukan penyediaan signage dan wayfinding yang berada didepan rencana akses masuk/keluar stasiun sebagai penunjuk lokasi dan arah untuk pejalan kaki dan pengguna angkutan umum dan dilakukan juga penataan pedestrian menjadi lebih lebar sesuai standar minimal dan ramah difabel. Beberapa ilustrasi penyediaan komponen integrasi yang diterapkan pada kawasan objek studi diperlihatkan pada Gambar 16 dan 17. 


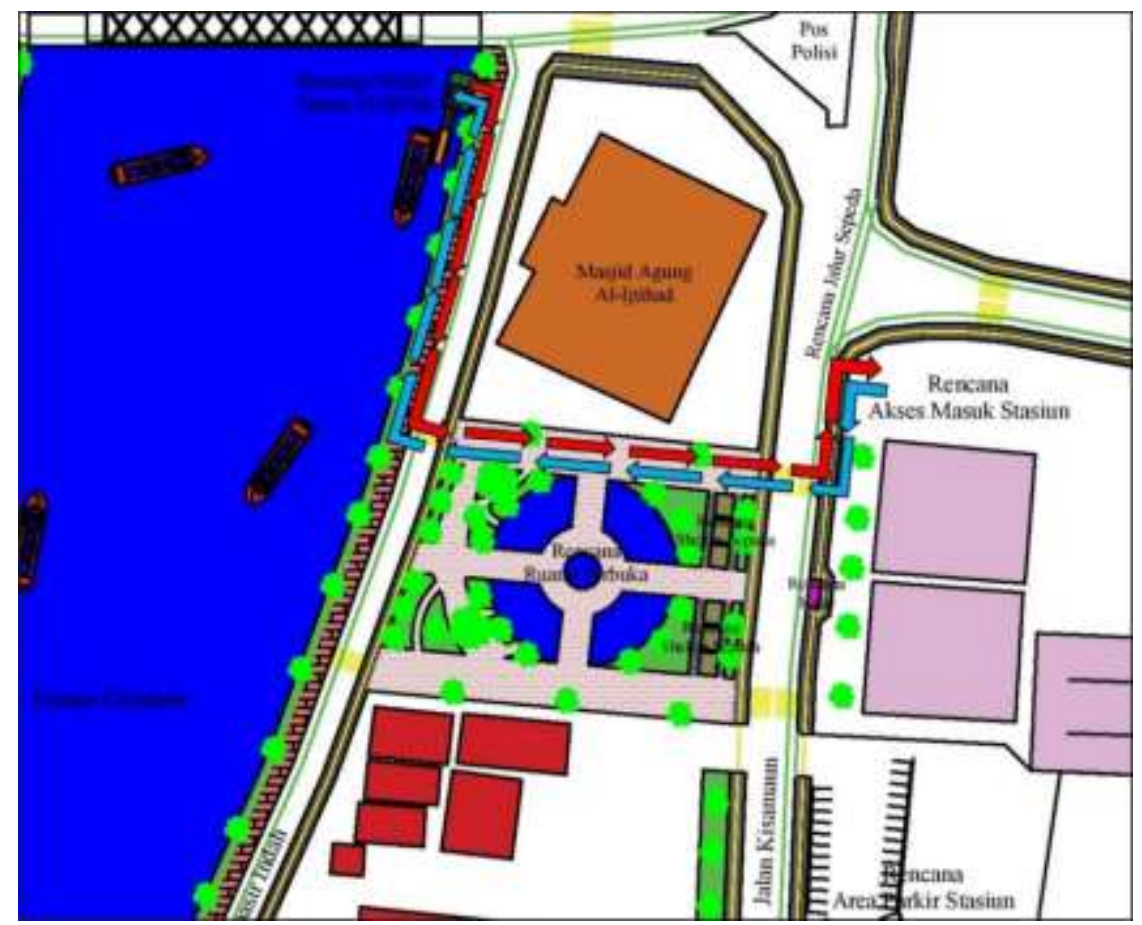

$\Rightarrow$ Sirkulasi Pcjalan Kaki Dermaga Transportasi Air - Stasiun KRL Tangerang

$\Longrightarrow$ Sirkulasi Pejalan Kaki Stasiun KRL Tangerang - Dermaga Transortasi Air

Gambar 15. Rencana Integrasi Kawasan dan Sirkulasi Pejalan Kaki Sumber: Hasil Olahan Pribadi, 2020

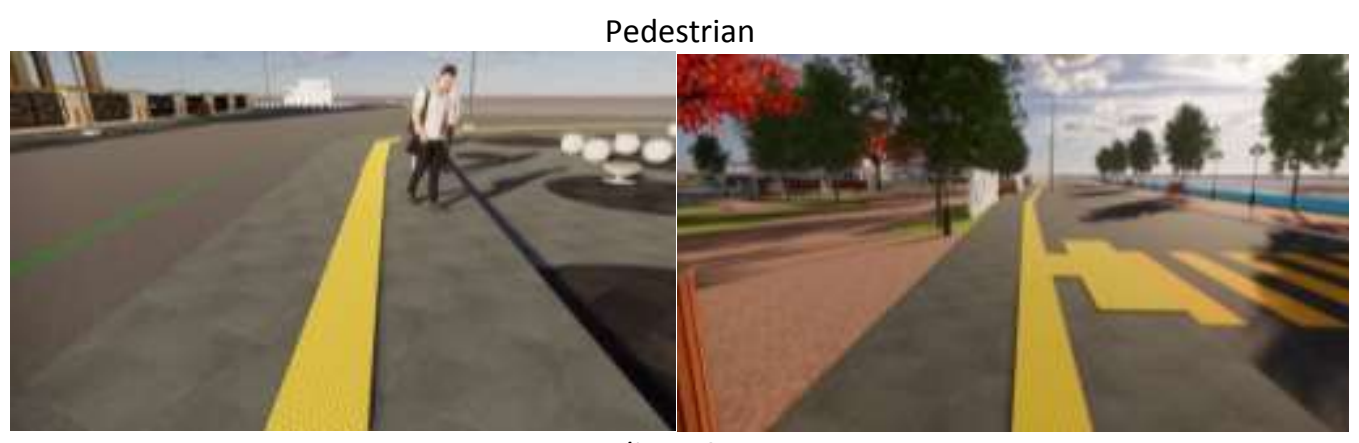

Pelican Cross

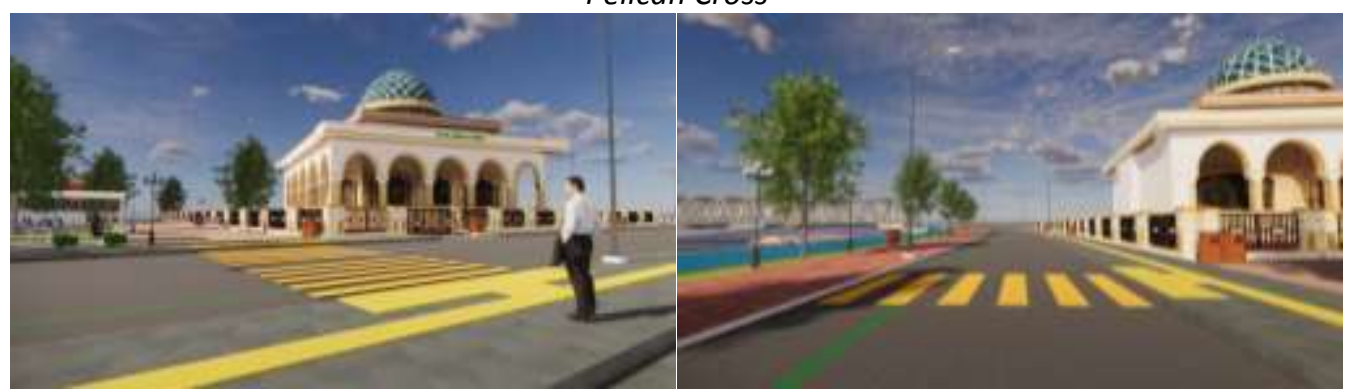

Gambar 16. Ilustrasi Penyediaan Komponen Integrasi Antarmoda Transportasi Sumber: Hasil Olahan Pribadi, 2020 


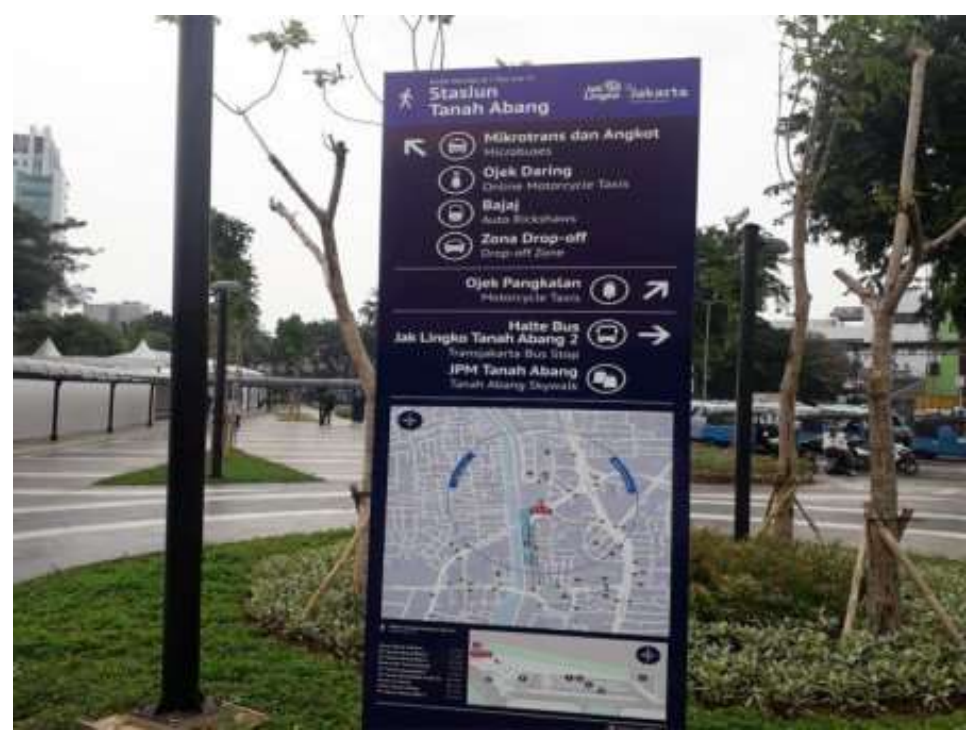

Gambar 17. Contoh Konsep Signage Dan Wayfinding (Stasiun Tanah Abang)

Sumber: Hasil Olahan Pribadi, 2020

\section{KESIMPULAN DAN SARAN Kesimpulan}

Jika melihat trend data ketinggian dan debit air sungai cisadane dalam 5 tahun terakhir dapat dilihat bahwa kondisi sungai cisadane mendukung dan memungkinkan jika diterapkan pengembangan transportasi air, kemudian dari seluruh analisis juga didapatkan arahan rencana penataan yang secara garis besar meliputi penyediaan ruang terbuka, pelebaran pedestrian, rekomendasi pemindahan akses keluar/masuk stasiun KRL Tangerang yang kemudian hasilnya berupa usulan rencana siteplan kawasan yang didalam rencananya terdapat unsur penyediaan kebutuhan sarana, prasarana dan fasilitas pada sekitar kawasan transit transportasi air dan penataan yang sesuai dengan arahan integrasi kawasan antarmoda yang berarti hasil konsep dan rencana tersebut telah menjawab tujuan dari penelitian ini.

\section{Saran}

Kawasan objek studi merupakan kawasan yang berada di pusat Kota Tangerang yang terdapat banyak beberapa pusat kegiatan di sekitarnya, membuat begitu banyak massa/orang dengan berbagai kegiatan yang ada disini, ditambah terdapat stasiun KRL Tangerang yang menjadi salah satu moda transportasi yang paling diminati oleh masyarakat Kota Tangerang, khususnya yang kebanyakan bekerja ke daerah jabodetabek lainnya dengan menggunakan moda transportasi ini, yang dapat dilihat jumlah penggunanya yang begitu tinggi dan trend penggunaannya begitu meningkat setiap tahunnya. Maka sebaiknya pemerintah melihat permasalahan-permasalahan yang ada di kawasan ini untuk membuat rencana atau penyediaan sarana prasarana untuk mendukung tingginya aktivitas massa pada kawasan. Dalam hal ini khususnya terkait dengan adanya rencana pengembangan transportasi air khususnya di dermaga masjid agung yang lokasinya berdekatan dengan stasiun KRL Tangerang, yang berpotensi menjadi titik transit perpindahan transportasi dari keduanya, sehingga sebaiknya pemerintah melihat dari adanya potensi tersebut untuk melakukan sebuah rencana penataan atau penyediaan sarana prasarana yang dibutuhkan seperti yang sudah dijabarkan pada penelitian ini. 


\section{REFERENSI}

Andriansyah. (2015). Manajemen Transportasi Dalam Kajian dan Teori.

Susilowati, E. (n.d.), (2011). Peranan Jaringan Sungai Sebagai Jalur Perdagangan Di Kalimantan Selatan Pada Pertengahan Kedua Abad XIX.

Department for Transport and the Department for Environment, Food and Rural Affairs., (2004). Planning For Freight On Inland Waterways.

Department of Irrigation and Drainage, Malaysia, (2011). Policy Policy Responses To Attain The Responses To Attain The Water Quality Target: Water Quality Target: Malaysia Malaysia Experience.

Kementerian Dalam Negeri Republik Indonesia, (1975). Ketentuan-Ketentuan Mengenai Tata Cara Pembebasan Tanah. Jakarta.

Kementerian Pekerjaan Umum Republik Indonesia, (2009). Pedoman Penyediaan Dan Pemanfaatan Ruang Terbuka Non Hijau Di Wilayah Kota/Kawasan Perkotaan. Jakarta, pp.20-34.

Kementerian Pekerjaan Umum Republik Indonesia, (2014). Pedoman Perencanaan, Penyediaan, Dan Pemanfaatan Prasarana Dan Sarana Jaringan Pejalan Kaki Di Kawasan Perkotaan. Jakarta.

Kementerian Perhubungan Republik Indonesia, (2004). Penyelenggaraan Angkutan Sungai Dan Danau. Jakarta.

Kementerian Perhubungan Republik Indonesia, (2015). Standar Pelayanan Penumpang Angkutan Penyeberangan. Jakarta, pp.7-12.

Peraturan Daerah Kota Tangerang, (2012). Rencana Tata Ruang Wilayah Kota Tangerang 20122032. Kota Tangerang.

Presiden Republik Indonesia, (2012). Pengadaan Tanah Bagi Pembangunan Untuk Kepentingan Umum. Jakarta: Wisnu Setiawan.

Presiden Republik Indonesia, (2008). Pelayaran. Jakarta. 
